\title{
The Mystery of Missing Female Children in the Caucasus: An Analysis of Sex Ratios by Birth Order
}

\begin{abstract}
CONTEXT: Official data on sex ratios at birth suggest a rise in sex-selective abortions in some post-Soviet states following the introduction of ultrasonography. However, questions remain about the validity of official data in these nations as well as whether the high sex ratios at birth are a statistical artifact.
\end{abstract}

METHODS: Trends in sex ratios at birth from 1985 to 2009 for 12 post-Soviet states were examined using vital registration data. For the three countries that had had a Demographic and Health Survey (DHS) in 2005-2010 (Armenia, Azerbaijan and Moldova), survey data were used to calculate sex ratios at birth according to birth order, and vital registration data for 2010 were used to estimate the number of "missing" female births (if any).

RESULTS: Official data revealed elevated sex ratios at birth in Armenia (117), Azerbaijan (116) and Georgia (121), but not in other post-Soviet states. According to DHS data, sex ratios were high in Armenia and Azerbaijan for first births (138 and 113, respectively); if the first child was a girl, the sex ratio in Armenia was even higher for the second birth (154). Overall, the number of girls born in these countries in 2010 was $10 \%$ lower than expected, consistent with 1,972 sex-selective abortions in Armenia and 8,381 in Azerbaijan. Sex ratios did not vary by birth order in Moldova.

CONCLUSION: Sex-selective abortion appears to be common in Azerbaijan and Armenia. Family planning and legal interventions are needed to address this issue.

International Perspectives on Sexual and Reproductive Health, 2013, 39(2):97-102, doi: 10.1363/3909713

In a landmark 1990 essay in the New York Review of Books, Nobel laureate Amartya Sen estimated that the number of women and girls in Asia was at least 100 million lower than expected, and suggested that this vast number of "missing" women "tell[s] us, quietly, a terrible story of inequality and neglect leading to the excess mortality of women." Although Sen's interpretation of a gender bias was initially challenged-for example, by the suggestion that hepatitis B was altering the natural sex ratio at birth in parts of $\mathrm{Asia}^{2}$ there is now widespread acceptance that the deficit in the number of women is the result of the combination of sexselective abortion (aided by easy access to ultrasonography), infanticide and childhood neglect. ${ }^{3}$

Both infanticide and childhood neglect act after birth to alter sex ratios. Only sex-selective abortion, however, can affect the sex ratio at birth. Biologically, the sex ratio at birth is about 105 boys for every 100 girls, an imbalance believed to be an evolutionary response to the elevated probability of death in childhood among boys. ${ }^{4.5}$ The sex ratio at birth is remarkably consistent across countries, with very few exceptions. ${ }^{6}$ Five of the exceptions-China, India, Vietnam, Hong Kong and South Korea-have been the subject of detailed and extensive research, ${ }^{7-9}$ other work has looked at specific ethnic groups or subpopulations, such as Asians in the United States. ${ }^{10}$ The former Soviet-bloc countries have received much less attention, apart from a study by Meslé and colleagues that suggested a rise in sex ratios at birth in some states of the Caucasus beginning in the mid-1990s. ${ }^{11}$

The increases in sex ratios at birth in the Caucasus appear to have coincided with the importation of cheap portable ultrasound machines after the collapse of the Soviet Union. Under Stalin, access to contraceptives and abortion were strictly limited in the Soviet Union as part of an effort to increase the birthrate in a country recovering from the ravages of war and famine. However, the wide-ranging reforms introduced by Khrushchev in 1955 liberalized access to abortion, which soon became available on demand. ${ }^{12}$ Although abortions were common in subsequent decades, access to contraceptives was very limited; use of hormonal contraceptives or IUDs was discouraged by most clinicians, and condoms and cervical caps were of questionable quality and in very short supply. ${ }^{12}$ The economic liberalization that accompanied the 1991 breakup of the Soviet Union eliminated the supply problems, but considerable financial barriers remain for many women in former Sovietbloc countries. Moreover, prejudices against hormonal contraception persist among health professionals. ${ }^{13-15}$ Consequently, abortion continues to be the main means of limiting fertility in post-Soviet countries, despite a growing antiabortion undercurrent in public and clinical discourse that reflects in part a resurgence of pronatalist policies in some countries. ${ }^{16}$ As many abortions are now believed to take place in private facilities (and thus are not included in
By Marc Michael, Lawrence King, Liang Guo, Martin McKee, Erica Richardson and David Stuckler

Marc Michael is assistant professor, New York University Abu Dhabi, United Arab Emirates. Lawrence King is reader, Department of Sociology, University of Cambridge, UK. Liang Guo is assistant professor, Rouen Business School, France. Martin McKee is professor, and Erica Richardson is honorary research fellow, Department of Health Services Research and Policy, London School of Hygiene and Tropical Medicine, UK. David Stuckler is senior research leader, Department of Sociology, University of Oxford, UK. 
FIGURE 1. Sex ratios at birth in selected former Soviet bloc countries, by five-year intervals, 1985-2009

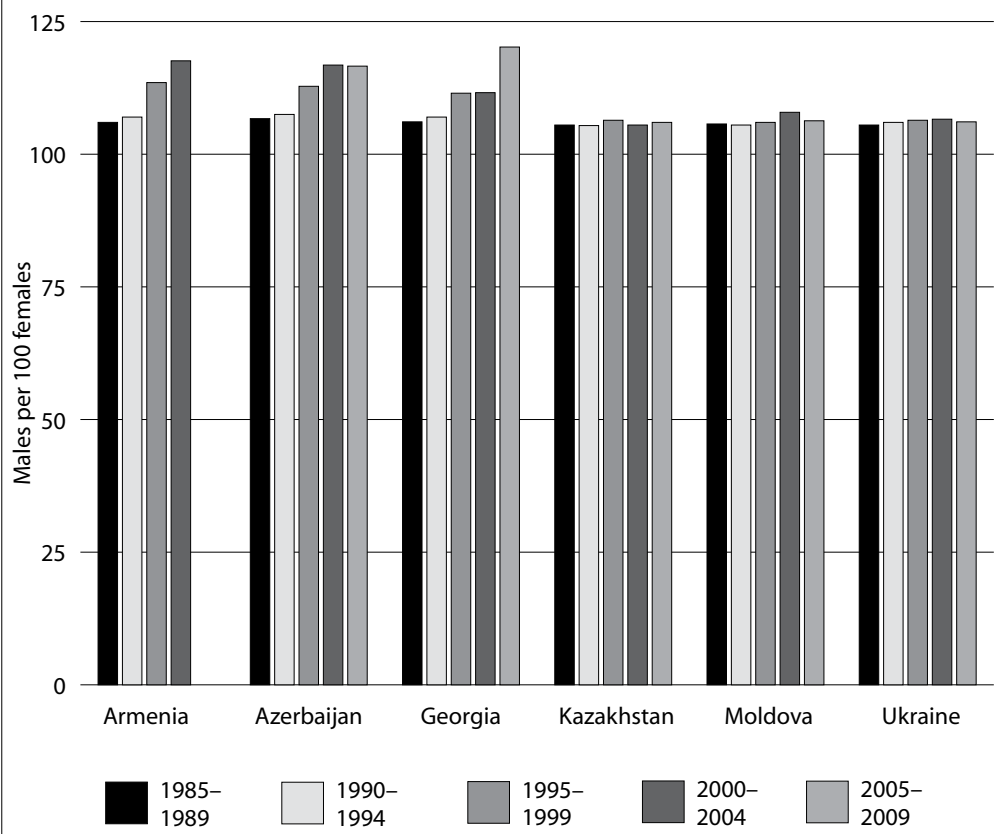

Note: Data for some years were unavailable for Armenia (2005-2009) and Turkmenistan (2000-2009).

official statistics), it is not possible to ascertain definitively whether rates have increased since the dissolution of the Soviet Union. However, for our present purposes it is not necessary to do so, as it is clear that abortions were already very common before the transition and that they remain so.

A crucial issue for our analysis is women's access to ultrasonography, which is needed to determine the sex of a fetus. Although introduced into clinical practice in the West in the 1970s, ultrasound machines were not widely available in Soviet-bloc countries during most of the Soviet period because of a lack of indigenous manufacturing capacity and because of Western restrictions on the export of technology with potential military uses. The situation began to change in the mid-to-late 1980s, coinciding with glasnost and perestroika; use of diagnostic ultrasound technology expanded rapidly, and by the late 1980s ultrasound was used widely in obstetrics and gynecology departments, as evidenced by a 1988 Ministry of Health order that set working norms for doctors employed in the ultrasound departments of women's health outpatient clinics. ${ }^{17}$ According to the document, these clinics, combined, had 3,000 Soviet-made ultrasound machines, 1,000 imported machines and more than 5,000 specialists working in ultrasound diagnostics. The situation changed dramatically after the collapse of the Soviet Union, as advanced medical technology could be imported much more easily; importation was facilitated by donations from abroad, and in particular from each country's diaspora communities. *

*It is important to stress, however, that no direct evidence links these donations with sex selection.
Because most ultrasound machines in the Caucasus are in private clinics, rather than in state facilities, reliable data that could be used to map the spread of this technology are lacking. ${ }^{11}$ Alternative methods of identifying the sex of a fetus, such as testing fetal DNA in a woman's urine $e^{18}$ or blood, ${ }^{19}$ are now available over the Internet; urine testing costs about US $\$ 30 .{ }^{20}$ However, these tests did not become widely available until about 2010, and thus could not have played a role (at least until recently) in any increases in sex ratios in Caucasian states. ${ }^{21}$

Taken together, the growing access to new technology and the preliminary evidence of an increasingly imbalanced sex ratio at birth strongly suggest that prenatal sex selection and selective abortion are widespread in some post-Soviet states. These occurrences, if confirmed, would be of considerable human and public health concern.

Yet, caution is required before we reach such conclusions, as the vital registration systems of former Soviet-bloc countries have suffered from the economic crises and state breakdowns that followed the political transition. For example, Georgia began imposing fees for birth and death registration; as a result, many families did not report vital events. ${ }^{22}$ Because of such issues, estimates of infant mortality derived from vital registration in post-Soviet countries differ greatly from survey-based estimates. In fact, some authors have theorized that any imbalances in sex ratios are an artifact of inadequate post-Soviet surveillance systems. ${ }^{23}$ For example, systematic under-registration of female births may be occurring, perhaps reflecting parents' unwillingness to incur the cost and effort of registration. However, the only previous study on this issue, which focused on Georgia and Armenia, suggested that under-registration of female births is not a plausible explanation. ${ }^{11}$

One method for testing whether sex-selective abortion may be contributing to imbalanced sex ratios is to examine whether the probability that a newborn child is male differs according to the sex of the parents' other children, an approach developed in India and China through the work of Das Gupta ${ }^{3}$ and Jha and colleagues. ${ }^{24}$ One can hypothesize that parents who wish for a boy may be willing to let nature take its course for the first birth but, if the resulting child is a girl, seek prenatal sex determination in the subsequent pregnancy. Meslé and colleagues' work, which did not include statistical testing, nonetheless suggested that the major contributor to the extraordinary sex ratios in Georgia and Armenia was the high proportion of males among third-born children. ${ }^{11}$ This finding provided support for the hypothesis that sex-selective abortion has been occurring in the Caucasus, although the authors stressed the need for more research, particularly on Azerbaijan, where the sex ratio is extremely high.

In this study, we used recent data from three former Soviet countries to test whether sex ratios at birth differ by birth order. In particular, we compared patterns in Armenia and Azerbaijan, which have both exhibited steep increases in sex ratios at birth, with the pattern in Moldova, which has a normal sex ratio and served as a "control" country. 


\section{METHODS}

The study data were obtained from two sources. First, we used vital registration data from 12 former Soviet states for the years 1985 to 2009; these data were supplied to the World Health Organization by the respective countries. Second, we obtained data from Demographic and Health Surveys (DHS) conducted in Armenia, Azerbaijan and Moldova, the three post-Soviet Caucasus states for which DHS data are available. The surveys asked women and men aged 15-49 about a wide range of demographic and other characteristics, including their reproductive history; full details of the sampling and content of each survey are available elsewhere. ${ }^{25}$ Our analysis focused on women who had had at least one birth. The survey in Armenia was conducted in 2010 and included 3,780 mothers; the survey in Azerbaijan was conducted in 2006 and included 5,252 mothers; and the survey in Moldova was conducted in 2005 and included 4,948 mothers.

We performed two analyses. First, we evaluated trends in sex ratios at birth for 12 former Soviet states to identify countries that may be exhibiting son preference. Second, for the states that had elevated sex ratios at birth (more than 115 boys per 100 girls), we calculated conditional sex ratios-that is, sex ratios at birth according to the number and sex of the mother's previously born children. We present these data using "decision trees" that show the probability of male and female births, and the equivalent sex ratios, for the first two birth orders. We then used these estimates to compare expected and observed sex ratios and to calculate the number of "missing" females in each country. We calculated the expected number of female births by dividing the observed number of male births by the natural birth ratio of 105 male per 100 female births. The difference from the observed number of female births yielded the number of missing females.

\section{RESULTS}

\section{Time Trends in Sex Ratios at Birth}

Of the 12 post-Soviet states, three-Armenia, Azerbaijan and Georgia-had sex ratios at birth of at least 116 in 20052009 (Figure 1). These ratios are as high as or higher than those reported in China and India (118 and 111, respectively). ${ }^{26}$ In all three of these Caucasus states, sex ratios have risen substantially since the late 1980s. No evidence of a similar phenomenon is apparent in Kazakhstan, Moldova or Ukraine (Figure 1), nor in any of the other former Soviet republics (see Web Appendix Figure 1), despite the fact that these countries have many characteristics in common with Armenia, Azerbaijan and Georgia.

\section{Conditional Sex Ratios at Birth}

According to the Demographic and Health Surveys, the mean number of children ever born to women with at least one birth was 2.4 in Armenia and 2.6 in Azerbaijan, but only 2.0 in Moldova (not shown). Decision-tree representations of sex ratio by birth order reveal markedly different patterns across countries. If the first child was female, the
FIGURE 2. Proportions of male and female children, and corresponding sex ratios at birth, by birth order, Armenia

First child Second child

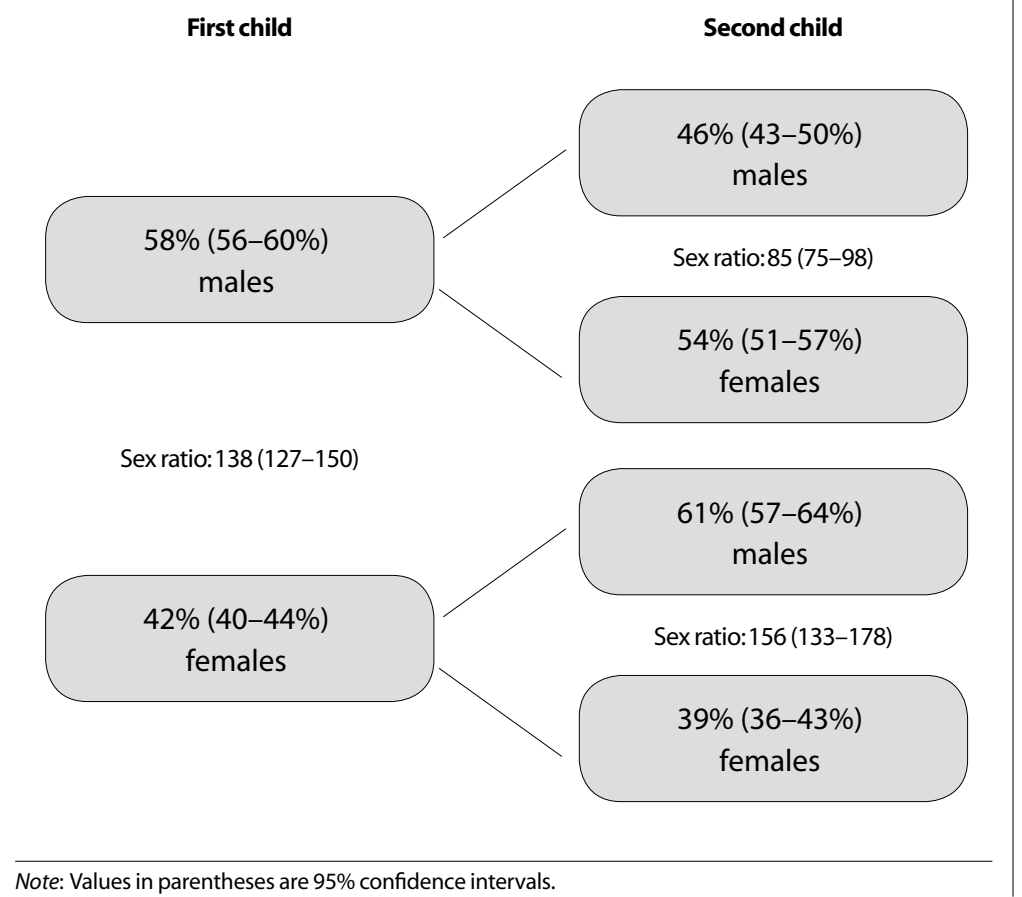

sex ratio increased or remained elevated with increasing birth order in Armenia (Figure 2) and Azerbaijan (Figure 3), but not in Moldova (Figure 4, page 100). No increases were apparent if the first child was male.

The overall sex ratio at birth in Armenia was 118 (not shown), slightly higher than that calculated from vital reg-

FIGURE 3. Proportions of male and female children, and corresponding sex ratios at birth, by birth order, Azerbaijan

First child Second child

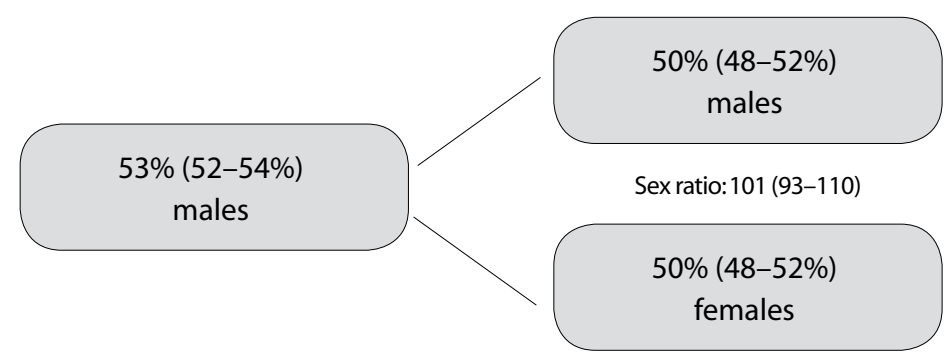

Sex ratio: $113(108-117)$

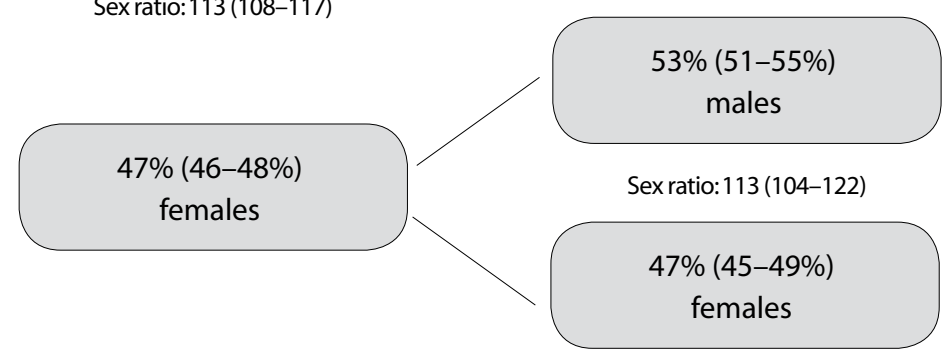

Note: Values in parentheses are $95 \%$ confidence intervals. 


\section{Figure 4. Proportions of male and female children, and corresponding sex ratios at birth, by birth order, Moldova}

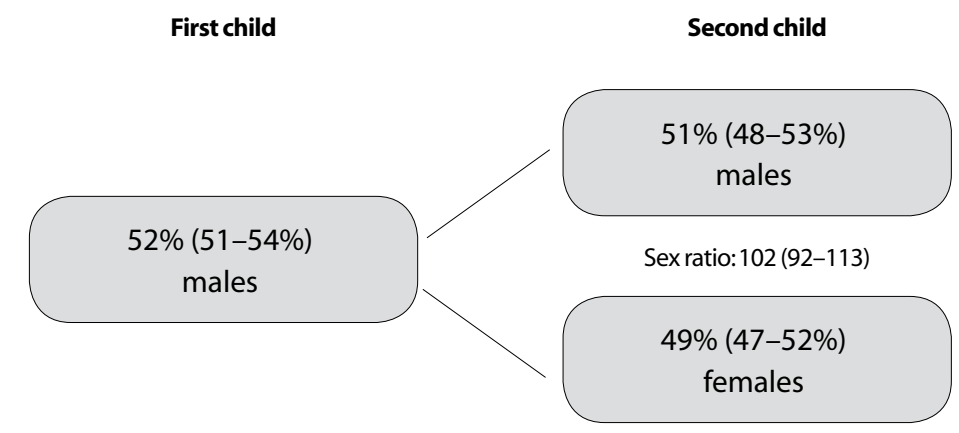

Sex ratio: $108(104-117)$

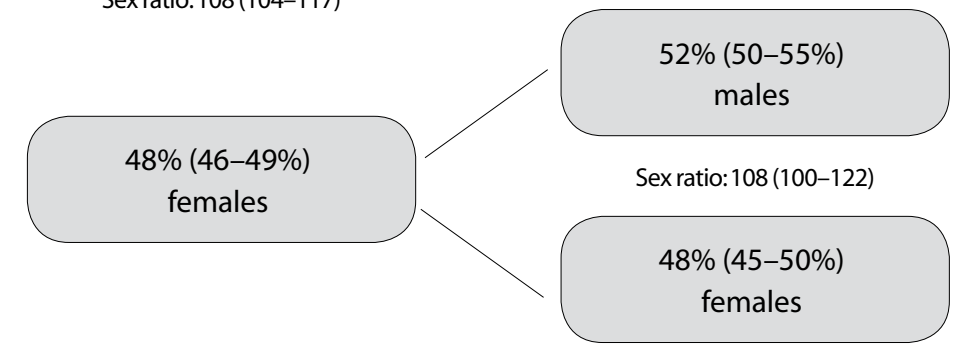

Note: Values in parentheses are $95 \%$ confidence intervals.

istration data. Fifty-eight percent of firstborn children were male, yielding a sex ratio of 138 (Figure 2), substantially higher than what would be expected naturally. For second births, the overall sex ratio falls to 109 (not shown); however, if the first child is a daughter, the probability that the second child will be a son is $61 \%$, equivalent to a sex ratio of 156 . For third births (not shown), the sex ratio remained abnormal if the first two children were both male (115) or female (141), or if the first was female and the second was male (148).

The overall sex ratio at birth in Azerbaijan is 115 (not shown), consistent with data from vital registration. Again, the ratio is already elevated at the first birth: Fifty-three percent of first-born children are sons, equivalent to a sex ratio of 113 (Figure 3). If the first child is a boy, the sex ratio for the second birth is normal. However, if the first child is a girl, then the probability that the second child will be a boy remains elevated (sex ratio, 113); if the first two children are girls, the sex ratio at birth for the third child increases further, to 128 (not shown).

As anticipated, we found no evidence of a deviant sex ratio at birth in Moldova. The overall ratio was 107 (not shown), and no significant differences in sex ratio at birth emerged at later birth orders-102 if the first child is a boy and 108 if the first child is a girl.

If the natural sex ratio at birth is 105 males per 100 females, we estimate that in 2010 there would have been 22,828 female births in Armenia and 84,890 in Azerbaijan-1,972 and 8,381 more, respectively, than were actually recorded. This suggests that almost $10 \%$ of potential female births in each country did not occur because of sexselective abortion.

\section{DISCUSSION}

Our study identified several instances in which the sex ratio at birth was considerably different from the naturally expected ratio, and the differences occurred in contexts consistent with use of prenatal sex determination and selective abortion. These observations provide strong evidence that the high sex ratios at birth are real and are not, as has been suggested, an artifact of the data. ${ }^{23}$ The proportions of female births in Armenia and Azerbaijan that are "missing" are substantial-about 10\%.

These analyses are limited by the small size of the Demographic and Health surveys. Thus, we cannot exclude the possibility that the true sex ratio at birth is higher than 105 in more scenarios than we have identified, and that as a result we are underestimating the scale of the problem. A further limitation is the absence of a recent DHS in Georgia, the third country in the region that has had a rapid increase in sex ratio at birth in recent decades.

Are the high sex ratios at birth that we observed attributable to sex-selective abortion? To reach such a conclusion, one must demonstrate the presence of easy access to both ultrasonography and abortion. As we noted earlier, both of these conditions apply to Armenia, Azerbaijan and Georgia. Although abortion has long been widely used in this region as a form of family planning, the context changed in the late 1980s, when the widespread introduction of ultrasonography made prenatal sex determination possible; the availability of this technology coincided with the rapid increase in sex ratio at birth.

Future research is needed to explain why a rapid increase in sex ratio at birth has occurred in Armenia, Azerbaijan and Georgia but not in other former Soviet-bloc countries, all of which have had the technological capacity to follow the same course. One possible explanation is that Azerbaijan and Armenia (but not Moldova) have been involved in so-called frozen wars ${ }^{27}$-protracted, violent ethnic conflicts that have occasionally intensified into prolonged states of insecurity. Such situations, by virtue of their extended nature and the general mobilization they entail, might greatly diminish women's bargaining powers in the public and private spheres, such that men's preference for sons determines couples' reproductive and family planning practices.

Our study has critical implications for family planning in the Caucasus. Although extensive research is needed to understand the mystery of missing female children in the Caucasus, our work provides sufficient evidence to establish the urgency of the issue in these countries and the need to regulate the use of prenatal sex determination. However, this approach has not been successful in lowering the sex ratio in India, ${ }^{28}$ which banned sex selection in 2002 , suggesting that legislation may be insufficient to address this problem if the regulations are not adequately implemented. Indeed, the most recent data show that the sex ratio imbalance in India has worsened in recent years. ${ }^{29}$ Reversing the corresponding trend in the Caucasus may prove particularly difficult without a clearer understand- 
ing of the social dynamics of female devaluation and son preference.

\section{REFERENCES}

1. Sen A, More than 100 million women are missing, New York Review of Books, 1990, 37(20):61-66

2. Oster E, Hepatitis B and the case of missing women, Journal of Political Economy, 2005, 113(6):1163-1216.

3. Das Gupta M, Explaining Asia's "missing women": a new look at the data, Population and Development Review, 2005, 31(3):529-535.

4. Fisher R, The General Theory of Natural Selection, Oxford, UK: Clarendon Press, 1930

5. Hamilton WD, Extraordinary sex ratios, Science, 1967, 156(3774): 477-488.

6. Parazzini $\mathrm{F}$ et al., Trends in male:female ratio among newborn infants in 29 countries from five continents, Human Reproduction, 1998, 13(5):1394-1396.

7. Das Gupta M and Li S, Gender bias in China, South Korea and India 1920-1990: effects of war, famine and fertility decline, Development and Change, 1999, 30(3):619-652.

8. Wong GY, Leung WC and Chin RK, Recent dramatic increase in the male-to-female sex ratio of babies born in Hong Kong, Journal of Perinatal Medicine, 2010, 38(2):209-213.

9. Guilmoto CZ, Son preference, sex selection, and kinship in Vietnam, Population and Development Review, 2012, 38(1):31-54.

10. Egan JF et al., Distortions of sex ratios at birth in the United States; evidence for prenatal gender selection, Prenatal Diagnosis, 2011, 31(6):560-565.

11. Meslé F, Vallin J and Badurashvili I, A sharp increase in sex ratio at birth in the Caucasus. Why? How? in: Attane I and Guilmoto C, eds., Watering the Neighbour's Garden: The Growing Demographic Female Deficit in Asia, Paris: Committee for International Cooperation in National Research in Demography, 2007, pp. 73-88.

12. Buckley M, Redefining Russian Society and Polity, Boulder, CO, USA: Westview Press, 1993.

13. Thompson ME and Harutyunyan TL, Contraceptive practices in Armenia: panel evaluation of an Information-Education-Communication Campaign, Social Science \& Medicine, 2006, 63(11):2770-2783.

14. Perlman F and McKee M, Trends in family planning in Russia, 1994-2003, Perspectives on Sexual and Reproductive Health, 2009, $41(1): 40-50$.

15. Regushevskaya E et al., Contraceptive use and abortion among women of reproductive age in St. Petersburg, Russia, Perspectives on Sexual and Reproductive Health, 2009, 41(1):51-58.

16. Rivkin-Fish M, Women's Health in Post-Soviet Russia: The Politics of Intervention, Bloomington, IN, USA: Indiana University Press, 2005.

17. USSR Ministry of Health, Order No. 581, July 21, 1988.

18. Al-Yatama MK et al., Detection of Y chromosome-specific DNA in the plasma and urine of pregnant women using nested polymerase chain reaction, Prenatal Diagnosis, 2001, 21(5):399-402.

19. Scheffer PG et al., Reliability of fetal sex determination using maternal plasma, Obstetrics \& Gynecology, 2010, 115(1):117-126.

20. United Nations Population Fund (UNFPA), UNFPA Guidance Note on Prenatal Sex Selection, New York: UNFPA, 2010.

21. Osipenko L and Szczepura A, Non-invasive fetal sexing: medical test or a new tool for sex selection? Diversity in Health and Care, 2011, 8(1):37-44.

22. Badurashvili I et al., Where there are no data: What has happened to life expectancy in Georgia since 1990? Public Health, 2001, 115(6):394-400

23. Tsuladze G, Melaadze G and Badurashvili I, Sex ratio at birth in Georgia, Saqartvelo, 1998, No. 1, pp. 145-154 (in Georgian).

24. Jha $\mathrm{P}$ et al., Low female-to-male sex ratio of children born in
India: national survey of 1.1 million households, Lancet, 2006 , 367(9506):211-218.

25. Measure DHS, Publications by country, no date, <http://www. measuredhs.com/Publications/Publications-by-Country.cfm>, accessed June 4, 2013.

26. Guilmoto CZ, Sex Imbalances at Birth: Current Trends, Consequences and Policy Implications, Bangkok, Thailand: UNFPA Asia and the Pacific Regional Office, 2012.

27. Horowitz S, War after communism: effects on political and economic reform in the former Soviet Union and Yugoslavia, Journal of Peace Research, 2003, 40(1):25-48.

28. Subramanian SV and Selvaraj S, Social analysis of sex imbalance in India: before and after the implementation of the Pre-Natal Diagnostic Techniques (PNDT) Act, Journal of Epidemiology and Community Health, 2009, 63(3):245-252.

29. Jha P et al., Trends in selective abortions of girls in India: analysis of nationally representative birth histories from 1990 to 2005 and census data from 1991 to 2011, Lancet, 2011, 377(9781):1921-1928.

\section{RESUMEN}

Contexto: Los datos oficiales sobre la razones de sexo al nacer sugieren un aumento en los abortos selectivos por sexo en algunos estados postsoviéticos luego de la introducción de la ultrasonografía. Sin embargo, todavía quedan preguntas sin responder acerca de la validez de los datos oficiales en esas naciones, y sobre la posibilidad de que las altas razones de sexo al nacer sean un error de observación.

Métodos: Se examinaron las tendencias observadas en las razones de sexo al nacer de 1985 a 2009 para 12 estados postsoviéticos usando estadísticas vitales. Para los tres países que habian tenido una Encuesta Demográfica y de Salud (EDS) entre 2005-2010 (Armenia, Azerbaiyán y Moldavia), se usaron datos de las encuestas para calcular razones de sexo al nacer según el orden de nacimiento; y se usaron estadísticas vitales de 2010 para estimar el número de nacimientos femeninos "faltantes" (si los hubo).

Resultados: Los datos oficiales revelaron elevadas razones de sexo al nacer en Armenia (117), Azerbaiyán (116) y Georgia (121), pero no en otros estados postsoviéticos. Según datos de las EDS, las razones de sexo fueron altas en Armenia y Azerbaiyán para los primeros nacimientos (138 y 113, respectivamente); si el primer hijo había sido una niña, la razón de sexo en Armenia fue aún más alta para el segundo nacimiento (154). En general, el número de niñas nacidas en estos países en 2010 fue un 10\% menor de lo esperado, lo cual es consistente con los 1.972 abortos selectivos por sexo que ocurrieron en Armenia y los 8.381 en Azerbaiyán. Las razones de sexo no variaron por orden de nacimiento en Moldavia.

Conclusión: El aborto selectivo por sexo parece ser común en Azerbaiyán y Armenia. Son necesarias la planificación familiar y las intervenciones legales para abordar este tema.

\section{RÉSUMÉ}

Contexte: Les données officielles relatives aux rapports de masculinité à la naissance laissent entendre une hausse de l'avortement sélectif, depuis l'introduction de l'échographie, dans certains états postsoviétiques. La validité des données officielles de ces nations reste cependant incertaine, de même que la question de savoir s'il s'agit là d'un artefact statistique. 
Méthodes: Les tendances des rapports de masculinité à la naissance, de 1985 à 2009 dans 12 états postsoviétiques, sont examinées d'après les données d'état civil. Pour les trois pays soumis à l'Enquête démographique et de santé (EDS) en 2005-2010 (Arménie, Azerbaïdjan et Moldavie), les données d'enquête ont servi à calculer les rapports de masculinité à la naissance en fonction du rang de naissance et les données d'état civil de 2010, à estimer le nombre de naissances féminines «manquantes» (le cas échéant).

Résultats: Les données officielles révèlent des rapports de masculinité à la naissance élevés en Arménie (117), en Azerbaïdjan (116) et en Géorgie (121), mais pas dans les autres états postsoviétiques. D’après les données d'EDS, ces rapports sont élevés en Arménie et en Azerbaïdjan pour les naissances de premier rang (138 et 113, respectivement). Si le premier enfant est une fille, le rapport est plus élevé encore en Arménie à la seconde naissance (154). Dans l'ensemble, le nombre de filles nées dans ces pays en 2010 est de 10\% inférieur à celui attendu, laissant entendre 1.972 avortements sélectifs en Arménie et 8.381 en Azerbaïdjan. Les rapports de masculinité ne varient pas en fonction du rang de naissance en Moldavie. Conclusion: L'avortement sélectif selon the sexe semble fréquent en Azerbaidjan et en Arménie. Des interventions légales et de planification familiale doivent être adoptées pour faire face au problème.

Author contact: david.stuckler@sociology.ox.ac.uk 